\title{
GALICH, WAS IT A REAL (PART OF) RUS'?'
}

\author{
Myroslav Voloshchuk
}

DOI: 10.17846/CL.2021.14.2.37-50

\begin{abstract}
VOLOSHCHUK, Myroslav. Galich, was it a real (part of) Rus'? Historical Galician land (земля Галичкая) during the 10th - 14th centuries remained the permanent intersection of civilizational influences that determined the ethnic background of the region, political orientations of the elites and local identity. For a long time since the end of the 11th century the local thrones were occupied by various branches of the Rurikids (the Rostislavovids and the Romanids), the bearers (with an official Orthodox Church support) of the concepts of "Rus" and the "Rusyns" in the politics and language. The presence of the Ruthenian princes in Galich (Halych) consolidated the perception of the region at the inter-dynasty level as a part of the "Ruthenian world". However, the local definition of the inhabitants as the Galicians (it is known as a separate term terminus post quem 1138) and their homeland as Galicia (Galician land), which had been known since 1152, allowed to coexist, periodically to conflict and systematically to "fight" with "Ruthenian" definition in the ideological and often military-political spheres. Only before the final inclusion of Galicia to the possessions of the Romanids dynasty, "Russification" ("Ruthenization") of this region (included to the uninstitutionalizated Kingdom of Rus' - Regnum Russiae) began after 1253. Hence, the Ruthenian identifications became stronger than Galician, influencing the perception of the Galician past and historical research during the 19th - beginning of the 20th century.
\end{abstract}

Keywords: The Rurikids, the Rostislavovids and the Romanids, Rus', Regnum Russiae, Galicia (Galician land), terminology

The affiliation of Galich (Halych) to the "Ruthenian (Rus'ian) land", or the "land of Rus"' (Poycb, Роусьскан землА, Рүссккан землА), which has been mentioned in the chronicles (летописи) and church literature since the 11th century ${ }^{2}$, was periodically discussed as an issue in the field of Russianistics and Mediaeval studies due to the prominent role of the city-policy during the 12th 13th centuries in the context of the Central-European history. The special studies by Henryk Paszkiewicz (Paszkiewicz 1996, 446-455; Paszkiewicz 2020, 96-108), Arseniy Nasonov (Nasonov 1951, 130-142), Dmitriy Obolensky (Obolensky 1971, 260-271), Simon Franklin, Jonathan Shepard (Franklin - Shepard 1996, 347-350, 366-367, 369; Franklin - Shepard 2009, 513-515, 527), Aleksandr Mayorov (Mayorov 2001, 89-187), Hardi Đura (Hardi 2002, 17-22) Serhii Plokhy (Plokhy 2006, 33-38, 40-41, 46, 50-51), Leontiy Voytovych (Voytovych 2015, 3-5, 26-30) are among the most indicative ones. The positive changes in the scholarly research of the Galician problems

1 I would like to thank Prof. Aleksandr Musin from Saint-Petersburg (Russia) for his very useful advice and consultation.

2 See, in particular, the reception of the concepts of the "Ruthenian land", "Ruthenian princes", the "lands of Rus"' for the "Києво-Печерський патерик" ("Kyiv-Pechersk Patericon") in the 13th century (Kashuba Pikulyk 2007, 12-13, 48, 50-52, 54-55, 58, 63, 66, 69, 79, 82, 84). 
that have recently appeared ${ }^{3}$, allow us to rethink the terminological and further historical aspects of these problems in a new way (Nagirny - Voloshchuk 2018).

In a scrupulous review of some methodological aspects of the medieval studies of "the heritage of Rus"', it becomes clear that there is a complete or partial discrepancy between the modern knowledge and the terminology used in the scientific and educational literature on the subject of medieval Rus' and concrete historical realities of the mentioned period for its separate lands. Historical (since the middle of the 12th century) Galicia occupies the main place in this process. It owes its name to Galich - the largest city of the region in the 12th - 13th centuries. There were three stages of its development: the pre-chronicle (the 9/10th - 11th centuries), the chronicle (the 12 th -13 th centuries) and the late medieval, widely-dated by the 14 th -18 th centuries (Tomenchuk 1999, 299-307). Both historically and archaeologically, through the constant expeditions of the scholars since the second half of the 19th century and especially in the Soviet times as well as after 1991, paradoxically, we are able to give only a very general answer to the key questions of the formation and development of the place which was so important in the past. Many problems remain open.

One of the key questions is whether Galich was Rus' or not from the historical-terminological point of view. If it was, then when, under what circumstances, and in what aspects of everyday life and cult of its inhabitants, was it manifested? If not, then why the concept of Galician Rus' has been investigated in the scholarly publications by the huge number of a supporters since the 19th century? The comprehensive review of the specification and supplementation of the medieval Rus' terminology causes the necessity to find the answers to these important questions for a clearer understanding of the historical past of certain lands of the modern Ukraine, the role and place of its people among other European gentes.

Historically the Galician land ${ }^{4}$, being quite attractive from the commercial and economic points of view, always remained at the intersection of the medieval inter-dynastic and trade links, which formed the ethnic background of the region, reflected in a number of archaeological cultures of the early Slavic and medieval times (Thracian Gal'stat, Pragues, Penkivska, Luka-Raikovetska, Carpathian burial mounds etc.). Later it was supplemented by the nomadic and semi-nomadic gentes (the Germans, Ghetto-Dacians, Sarmatians, Alans, Croats, Pechenegs, Cumanians, Tatars, and Vlachs) settled in these lands. It affected the formation of numerous ethnic groups, local names of the inhabitants (the Hutsuls, Boykos, Pokutians, Lemks, Bukovinians) (Kochkin Nikitin 2009, 43-58) of this land.

Unfortunately, we do not know the actual geographic or political definition of the city or the region borders until the 12th century. Information from the "Kyiv-Pechersk Paterycon" (from the 13th century) about "Galician salt" at the end of the 11th century (Kashuba - Pikulyk 2007, 82) or the contemporary anonymous "Gesta Hungarorum" ("The Deeds of the Hungarians") (Jakubovich - Pais 1998, 47-50) about the location of Galich during the migration of Magyar tribes to Pannonia in the late 9th century is far from ideal.

The diverse world of religious ideas of its inhabitants, and also their culture, education, life and so on, are still known only partially (Tomenchuk 2018, 10-42). Only a few foreign sources ${ }^{5}$

3 See the publications of both series of the Collection of academic works "Галич" (Voloshchuk 2016-2020a; Voloshchuk 2016-2020b).

4 For the first time the "Галичане" ("Galicians") were known since 1138 (Kloss 2001a, 305), “Галич" (“Galich”) - since 1141 (Kloss 2001b, 304), “землю Галичкую” (“Galician Land”) - since 1152 (Kloss 2001b, 448).

5 In particular, it is an issue discussed in the writing of the emperor Constantine VII Porphyrogenitus (905 - 959) between 948 and 952, in the "De administrando Imperio" ("On the Administration of the 
give us some information about the settlement in the Pre-Carpathian territories by the Croats (that nowadays are mostly the part of modern Ukraine, partly of Slovakia and Poland) and about the existence of so-called Great Croatia (by the emperor Constantine VII Porphyrogenitus) at least till 992 AD (Moravcsik 1967, 153; Mayorov 2006, 166-169; Voytovych 2011, 40-44; Alimov 2016, 249-255). At the end of the 10th century, as a result of several large-scale archeologically proven military campaigns, the Croats were conquered by the Kyiv princes, especially Volodymyr Sviatoslavovych (960 - 1015) (Tomenchuk 2018, 35-36). So these lands, more or less, until the middle of the 14th century, with interruptions at the end of the 12th century and in the first half of the 13th century, belonged to the Rurikids. This dynasty had been associated with the cultural and religious promotion of the concepts of the Rus' in the narrative tradition, as well as in the Western European and Greek historical tradition.

Galich and, without a doubt, from the middle of the 12th century, Galician land occupied a special place in the possessions of the Rurikids. Unfortunately, the identification of its inhabitants (princes, elites, and lower segments of the population) of the mentioned period is known exclusively by the sources written outside the capital. It undoubtedly belonged to the large centers of the chronicle tradition and systematically "supplied information" to the scriptwriters of monasteries and cities from the different countries in the 12th - 13th centuries. It can be seen in the independent "Galician" passages of the Kyiv chronicles (летописи) since the 12th century (Kotliar 2009, 13; Yurieva 2017, 20-23).

The city belonged to a group of grandiose Croatian settlements (Plisnesk, Revna, Stylske, Iliv, etc.), stretching along the course of the Upper Dniester, bordering on its lower part with the settlement of the Ulychs and Tiverts (gentes), and closely coexisting with the carriers of the Scandinavian subculture at least in the 10th century (Liwoch 2003, 213-297; Liwoch 2005, 37-59; Liwoch 2006, 77-87; Liwoch 2011, 89-100; Liwoch 2018, 130, 135, 161, 163-164). Intercultural relationships affected the origin of the city's name and the identity of its inhabitants. The name Galician grave (now in Kachkiv, Krylos village, Galich district, Ivano-Frankivsk region, Ukraine) was mentioned between 1208 - 1211 in the Galician-Volhynian Chronicle (the Chronicle of the Romanids). Its origin for unknown reasons was not discovered by the chronicler of the 13th century, but he could explain the name of the city (Dąbrowski - Jusupović 2017, 24-25). Until 1991 the problem remained unresolved, and the place of burial ground was not localized. The discovery of the cenotative Galician grave and its research during 1991 - 1992 allowed us to connect the city-making processes and the name of the settlement with a remarkable person of Scandinavian (Varangian) origin (modern scientists have no doubt about it). There have been found many items of exactly Scandinavian (but not Slavic or other) cultures (Gutsuliak - Drohomyretskyy Tomenchuk 2005, 14-26; Tomenchuk 2006, 14-21; Baran - Tomenchuk - Figurnyy 2017, 15 17). It seems that we are talking about the analogy to the Polotsk variant of the centre that was accessible from the economic and commercial point of view and was also captured during the Kyiv prince's military campaigns. Of course, no kind of Rus' self-identity of the region or the city in the 9th - 10st centuries was mentioned. At least the sources are "silent" about this.

The conquest of Galich in 992/993 by Prince Volodymyr Sviatoslavovych caused a rather long period of decline in this area. After that period, as we know from the Kyivan and Volynian chronicles (летописи), as well as from the foreign narrative sources of the 12th - 13th centuries, within a relatively short time in the 12 th century this city quickly gave a name to the region and

Empire"), in the testimony of the Arabian and Persian travelers, as well as in the "Повесть временных rem" ("The Tale of Bygone Years") of the early 12th century. 
its inhabitants ${ }^{6}$. Many sources since the 12th century mentioned the names of Galicia (in the Latin version Galitia, Galithia, Galicia, Galatia and others, in the Middle Greek - Гó $\lambda ı \tau \zeta \alpha$ ), Galician lands and the Galicians (Kloss 2001b, 558; Kloss 2001a, XXXVI) that are obviously (self)identities which arose as a result of systematic contacts of the elites and the enlightened stratum of the medieval society from the different countries. This principality, though not big in a territory, but rather prosperous, was acquired by the Princes Rostislavovids around 1084 and became widely known. The collection of the West European Latin language texts ${ }^{7}$, as well as the sources written in the Middle Greek ${ }^{8}$ or Arabic (Konovalova 1999, 133-142) during the 12th - 13th centuries are the most typical in this regard from our point of view.

The descendants of Prince Volodymyr Sviatoslavovych, Rurik ( $†$ 1092), Volodar ( $† 1124)$ and Vasilko ( $† 1124 / 1125)$, probably with the consent of the local elites, received the right to take possession of Przemysl, Zvenigorod and Terebovlya, which was backed by the princely congress in Liubech in 1097. The land was centralized in 1141 with the capital in Galich (Kloss 2001a, 257; Cross - Sherbowitz-Wetzor 1953, 187; Kloss 2001b, 230-231). The existent Rurikids undoubtedly should have been the bearers of the concept of Rus'. At least in such reception they are presented in the official court chronicles (летописи). Everything that falls into the Rurikids spheres of influence and power is Rus' in the broad sense from the chronicler's (летописеи) point of view. However, a thorough analysis of the written sources of various origin convinces us about the controversial character of this terminology.

The concepts of Ruthenia or Ruscia are well known and used in the Western European history during the late 11th-12th centuries exclusively as related to the states of the Rostislavovids ${ }^{9}$. In our opinion, these definitions have become of the universal type, demonstrating the belonging of these lands to the members of the Rurikids family, from which the named three princes came out. All lands controlled by the Rurikids from Novgorod in the North to Tmutarakan' in the South and from Przemysl in the West to the Zalissya lands and the Over-Volga region in the East, were understood in the western courtyards and scribes as something integral from dynastic, probably confessional and partly culturally point of view ${ }^{10}$.

However, other definitions that best reflected the mentality and local features of the culture, self-awareness and self-perception, as well as attitude towards "them", "strangers" and "others"

6 In short, in the European practice, in addition to Rome, which originated the Romans and subsequently Moscow with its Muscovites (Moscovites), this is chronologically the second case (Voloshchuk 2016, 7).

7 See (Voloshchuk 2010, 165-178; Voloshchuk 2014, 113-125). In our opinion, in most cases, the Galician and Russian/Ruscian (Ruthenian) terminology are contradictory, thus reflecting less or more precise understanding by the authors of the texts of the historical realities of the described time.

8 Applying to the Galician rulers and the local population the concepts of Tavroskifiya and Tavroskifs

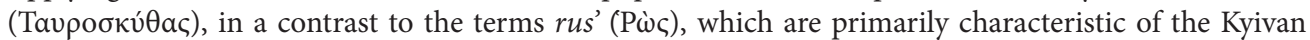
princes, the Greek authors also used the typical Galician nomenclature - Гa $\lambda$ í $\zeta_{\eta} \varsigma$ (Maineke, 1836, 115.1419, 232.7; van Dieten 1975, 129.29-30, 522-523; Ephraemii monachi imperatorum et patriarcharum

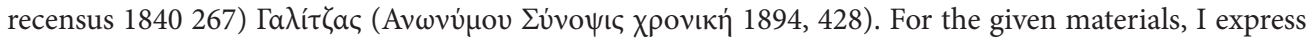
my deep gratitude to Olga Kozachok from Lviv, Ukraine (Kozachok, 2017, 146-147). On the topic see the "Ruthenian" terminology (Rossia, Ruthenia) in the German and Middle Greek languages of the middle of the 12th century (Nazarenko, 1999, 166-179; Bibikov 2004, 117, 119-120).

9 The Ukrainian historian Vitaliy Nagirnyy at the International Conference Colloquia Russica, Series II on "Medieval Rus': Problems of Terminology", (May 25-27, 2017, Ivano-Frankivsk and Galich, Ukraine) presented the topic "The Galician Principality" or "The State of Rostyslavovychs"? but has not published it.

10 See the content of agreements of the princes of Smolensk with Riga, where "смолн†\#нинъ" and "русин" are noted, as different from the Ruthenian (Rus'ian) law (Avanesov 1963, 10-13, 20 -35 etc.). Similar motives of contrasting the "movement" with other neighboring lands are also present in the Novgorod chronicles (летописи) (Forbes - Michell 1914, 26, 30, 36, 51-52, 62 etc.). 
were formed and gradually fixed in the narrative sources of the foreign, regional, national or international (here - the Ruthenian) origin (Voloshchuk 2010, 165-178). Undoubtedly, the princes Rostislavovids were considered in Galicia as native princes, despite their dynastic origin ${ }^{11}$. But the elites strongly influenced the princes' life ${ }^{12}$. The prince and boyar elites of the neighboring lands (controlled by the Rurikids, in particular, Volynian Volodymyr, Kyiv and Chernihiv), were perceived as the "others" and sometimes as "strangers". This opposition can be seen in Kyivan and Volhynian chronicles (летописи) of the 12th - 13th centuries which used Galician oral and written memory.

Here are some examples. Thus, during the so-called Battle of Holohory in 1144, we read: “взидоша Русскъии полци [Prince Izyaslav Davydovych. - M. V.] на горъ1 . и заидоша и $\overline{\mathrm{w}}$ Перемъшлл . и $\overline{\mathrm{w}}$ Галича . видъвъше же то Галичане. сътъснушаси рекуще . мъ1 сде стоимъ1 . а жнамо женъ1 нашъ възмуть” (Kloss 2001a, 311-312) ${ }^{13}$. A similar example is the collision of Izyaslav Mstyslavovych (1097 - 1154) with the Galician prince Yaroslav Volodymyrkovych in 1153 (Kloss 2001a, 340-341; Kloss 2001b, 465-468). The campaign of the "land of Rus" against Galich was noted in the Novgorod first chronicle (Новгородская первая летопись) in 1145 (Forbes - Michell 1914, 18). The negotiations of the Galician Prince Volodymyrko (near 1104 - 1152) with the ambassador of the Kyivan ruler Izyaslav Petro Boryslavych (about returning the number of cities promised by Volodymyrko to him) in 1152 became well known. After the Galician ruler refused to fulfill the promise, that was made

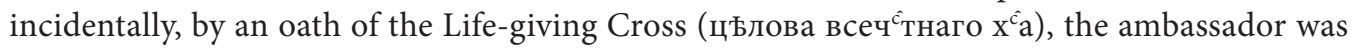
sent away from Galich: “[...] пођди же къ своему кизю Петръ же положа ему грамотъ1

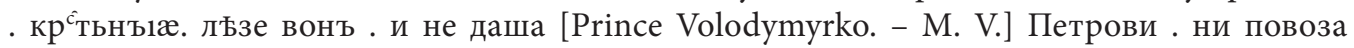
ни корма Петръ же поъха на свои ${ }^{\hat{x}}$ конихъ. и æкоже съъха Петръ съ кнАжа двора и Володимиръ поиде к божници . къ ст̈му С̆̈су на вечернюю . и æкоже бъ1 на переходъ ${ }^{\hat{x}}$.

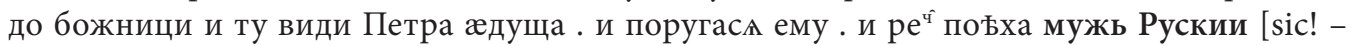
M. V.] шбуимавъ вс^ волости и то рекъ” (Kloss 2001b, 463-463). Therefore, the question arises: didn't the Galician prince consider himself to be the Ruthenian (Rus'ian), as if related to the Rurikids biologically or genealogically? Apparently - not to the end; not to mention the selfidentification of the inhabitants of all the land that he owned. Under 1202 it was written: "Романъ скопА полкъ. Галичьскыъ. и Володимерьскыъ. и въъха в Русскую землю” (Kloss 2001a, 417). Finally, there is the appeal of the Galician boyar Volodyslav Kormylchych to the citizens of Przemysl in 1210/1211 in order to expel Prince Svyatoslav from the Ihorids family, who was the

11 Carried out in 2017 the DNA analysis of the remains of the Galician prince, whom some scholars consider to have been Yaroslav Volodymyrkovych, and who was nicknamed in the "Слово о пълкоу Игоревп" ("The Tale of Igor's Campaign") as Osmomysl, - investigated by the Ukrainian archeologist Yaroslav Pasternak in 1937 (Zholob - Koval - Stasiuk 2018, 107-115), - causes serious doubts in his dynastic affiliation, perhaps due to the parental origin and therefore - to the review of his relationship with his contemporaries - the Kyiv, Chernihiv, Smolensk rulers, whether they were the representatives of the same genus "by the sword" ("for men's line"). See the documentary historical film "Повернення" ("Return") (https://www.youtube.com/watch?v=3pitjzmz0Uo), as well as the results of the official report on the Prince's remains from the Paleo DNA Lab of the University of Lakehead (Expert - Stefan Fratpietro), published there, for which we express our sincere gratitude to Igor Piddubnyy from Kharkiv, Ukraine (see below).

12 The most eloquent example is the capture and burning of the alive mistress of the Galician prince Yaroslav referred in the chronicle as Nastasia from the nomadic genus of Chagr: "Галичани же накладъше шгнь сожгоша ю а сна еæ в заточение послаша . а кн^з^ водивше ко крс правду. и тако оуладивъшесл" (Kloss 2011b, 564).

13 See also: Liaska 2017, 12-14. 
representative of the Chernihovian Olgovids: “реч[е] им[ъ]: «Братїе, по|что смоущаетес^? Не сеи ли избиша шт[ь]ци ваши и | братїю вашю, а инїи имънїа ваша разграбиша и | дъщери ваша даша за рабы ваша, а жт[ь]чествїи ва|шими владъша инїи пришел[ь]цих? То за тъх[ъ] ли хоче|те д[у]шю свою положити?” (Dąbrowski - Jusupović 2017, 33). An epic confrontation of a large part of the Galician boyars ${ }^{14}$ and the Romanids in the first half of the 13 th century deserves particular attention.

The concept of the Galician land and the Galicians (in the broad sense of the term beyond the limits of Galich city policy ${ }^{15}$ ) was approved in the territories controlled by the Rostislavovids in the 12th century. This concept gradually penetrated beyond the borders of their domain, mainly to their closest neighbors that had common economic interests and the genealogical ties with them. The awareness of Galicia as something different from the rest of Rus' in official documentation is evidenced for the first time in the Galician titulature (Galaciae Rex - the King of Galicia (Hardi 2018, 251-264)) of the Hungarian King Bela III (1172 - 1196) used on May 2, 1189 and June 26, 1190 (Smičiklas 1904, 234, 247). His son Andrew II (1205 - 1235), after the meeting with a widow of Prince Roman in August 1205, converted this casus in the dynastical tradition (Galitiae Lodomeriaequae Rex - the King of Galich and Volhynian Volodymyr lands), existing in the royal Hungarian practice till the beginning of the 16th century (Font 2005, 196). According to the Bratislava-Vienna treaty of 1515, the death and defeat of King Louis II (1506 - 1526) from the Jagiellonian dynasty in the Battle of Mohács on August 29, 1526, the "Galician titular heritage" was acquired by his Austrian relatives of the Habsburg family. Theoretically they possessed it until 1772 , and practically until November $1918^{16}$. However, the Hungarian royal dynasties during the 12th - 14th centuries did not appeal only to Galician and Volhynian titulature and did not consider Galich and the Galician land as Ruthenia in general (Voloshchuk 2014, 120, 122). Repeated use of the title Ruthenorum Rex (Procházková 2016, 208-212; Font - Barabás 2017, 42) by the Galician King Koloman (1208 - 1241) after 1215 requires additional study on the meaning of the terms Rutheni and Ruthenia in the Hungarian intellectual environment.

The Galician concept could supplant the Ruthenian during the first half of the 13th century in the circumstances of the opposition of a part of the local elites to the Princes Danylo (1200/01 $1264)$ and Vasilko (1203 - 1269), the heirs of Roman (1155/1156 - 1205), the "autocrat of all Rus", who died on June 19, $1205^{17}$. His sons personified the Ruthenian (Rus'ian) tradition in titulature and in practice. Undoubtedly, both brothers were associated with the "world of the Rurikids" among the Western European courts, and Galich belonged (but sporadically), only on the ideological level to

14 See the biohrams of the boyars (Jusupović 2013, 99-304).

15 In a similar context see a modern analysis of the concepts the "Ruthenian (Rus'ian) land" (Kuchkin 1995, 74-100; Vediushkina 1995, 101-116).

16 The Hungarian and hence the Austrian (later - Austro-Hungarian) monarchs used the title "king of Galicia" since the end of the 12th century. During the years 1387 - 1772 the historical Galician land was the part of the Polish kingdom (Regnum Poloniae), and since 1569, the part of the Polish-Lithuanian Commonwealth (Rzeczpospolita). The situation changed only after its first division, when Maria Theresa (1717 - 1780) became Dei gratia Galliciae Regina Apostolica, as well as the ruler of Hungary (in practice Dei gratia Galliciae Regina Apostolica), for the first time since Louis I of the Anjou dynasty (1342 - 1382) (Gall 1992, 50).

17 The reasons for the using of the characteristically chronicle's (летолись) passage to the Prince Roman are due to the long sphragistic tradition, which was begun by his direct ancestor Vsevolod Yaroslavovych (1030 - 1093), married at the first time to the daughter or a close relative of the Emperor Constantine IX (1000 - 1055). The title of "princes of Rus"' or "princes of all Rus" remained with this branch of princes (Alfyorov 2012, 143-146; Alfyorov 2016, 9-16). 
this "world of the Rurikids". Their direct fiefdom was the land of Volynian Volodymyr, which was also known abroad and was reflected in both Romanids's intitulations.

The sources dated terminus ante quem 1245 - 1246, mostly mentioned princes Danylo and Vasylko in general as dux Ruthenorum ${ }^{18}$, dux Russiae, illustrissimus Dux etc. (Voloshchuk 2017, 105). Even when they held the Galician throne, the closest neighbors knew the permanent titular (Galitiae Lodomeriaequae Rex) and sometimes their ownership of Galicia (1205 - 1206, 1207/8 $1208 / 9,1214$ - 1221 with interruptions, 1228 - 1234 with interruptions) to the Hungarian King, and the representatives of his family. Even the Ruthenian princes, set in Galich, in one way or another were compelled to recognize the nominal or real dependence on the Kingdom of Hungary (Voloshchuk 2014, 151-152). However, after the Romanids' victory under Yaroslav on August 17, 1245 over the united Hungarian-Polish troops reinforced by hostile units of the Galician boyars, the return of Prince Danylo from the voyage to Mongol Khan Batu ( $\dagger 1255 / 56)$ in 1246 and more active contacts with Pope Innocent IV (1243 - 1254), the palette of the famous titles of both Romanids has changed significantly, though not in favour of the Galicia. Correspondence with the Pontiff since 1246 shows a peculiarly complex identification of Danylo as Illuster Rex Russiae, and his brother Vasylko as Lodomerie Rex, Laudemerie Rex (Welykyi 1953, 30, 33, 35-36, 38-42, 50-51).

These titles, especially Danylo's, in no way contradicted the titles of the Hungarian rulers, and even practically expanded their use in independent lands, which in the dynastic ideology of the princes were considered the "Ruthenian", "Rus'ian". Galicia, of course, belonged to these lands. The beginning of the process was the official coronation of Prince Danylo at the end of 1253 and the right de iure to use the title of Rusciae Rex. Historically, the prospect of the rise of the Kingdom of Rus' (Regnum Russiae) was opened. The institutional organization of it has been studied so far only very superficially (Grechylo 2008, 260-276; Odnorozhenko 2009; Voloshchuk 2019, 84-95).

The final occupation of the Galician land by the Romanids in the mid of the 13th century and the recognition by the part of the elites of their suzerainty led, first of all, to the loss of the main princely residence status of Galich in favour of Holm and Lviv. Consequently, it caused slow demographic downturn and economic decline. The smooth Rus'ification (Ruthenization) of Galicia continued (here not to be confused with the notion of "Russification" ("зросійщення") inherent in the Ukrainian-Russian relations of the 18th-20th centuries) and transformed it into a peculiar outpost of Rus' led by the heirs of King Danylo.

Even after the loss of opportunity to use the royal titulature in the relation to their own lands, they used its more neutral forms, always emphasized the affiliation with the "Rurikids (Ruthenian or Rus'ian) world", and retained the Regnum Rusciae concept for more than 150 years. Lev Danylovych ( $†$ 1301), known in the foreign narratives as the King of Rus' (rex Ruscie) (Zemek 2003, 78), in diplomas rather avoided such a title because of the dependence on the Chingissids (Kupchynskyy 2004, 138, 529-530, 552, 569). His son, Yuriy I († 1308/15), with the only survivor seal, is known as Rex Rusie, Dux Ladimerie (Kupchynskyy 2004, 147-148). The heirs of the ruler, Lev II ( $† 1323)$ and Andrew ( $† 1323)$, however, were titled as Dei gratia duces totius Terrae Russiae, Galiciae and Ladimiriae (Kupchynskyy 2004, 150-151). In this case, other variants of the title are also known, including Prince Andrew as dux Ladimiriae et dominus Russiae, dux Ladomiriensis et dominus Terrae Russiae (Kupchynskyy 2004, 156, 160). Instead, his nephew Yuriy II Boleslav ( $\dagger 1340$ ), preserving, on the one hand, the princely title dux Russiae, dux Terrae Russiae Caliciae and Ladimeriae, dux et dominus Russiae, dux totius Russiae Minoris (Kupchynskyy 2004, 169, 172,

18 Here it is important to note the distinction of Koloman's title the Ruthenorum Rex which in the feudalized world hierarchy was higher than Danylo's title Ruthenorum Dux. 
$178,185)$, sometimes appealed to the royal traditions of his predecessors in the dux et heres Regni Russiae (Kupchynskyy 2004, 190) title and in his own seals he is titled as Georgius Dei gracia Rex Russiae (Mykhailovskyy 2013, 705-706; Longinov 1887).

Thus, Galicia and its inhabitants became an integral part of the Kingdom of Rus'. From an ideological point of view, they all became narrated in the sources as the Rutheni (as since the end of the 11th century). At the same time, the Galician terminology was definitely preserved in the oral tradition among inhabitants of the region, and before Galician Metropolis appearance in 1302/03 the mentioned terminology was noted in the church documents (Skochylias 2011, 246-279). The Rus/Rusyn (wider) and Galician (narrower) definitions undoubtedly co-existed in Galicia after the decline of the Kingdom of Rus' in the second half of the 14th century and during the subordination by the Kings of Poland 1387 - 1772 (since 1569 - Polish-Lithuanian Commonwealth). The famous chronicler Jan Długosz (1415-1480) knew and used the term terra Haliciensis in the second half of the 15th century (Wyrozumski 2005, 107). Galician terminology is also known in the sources of the 14th - 18th centuries in the governing bodies of Galician Land of Palatinatus Russiae, like Haliciensis starosta, castellanus, ensiger, notarius, pocillator and others (Przyboś 1987, 35-77). It means that a partial preservation of "Galician memory", which was insufficient for more long-time memory, existed.

However, the Ruthenian self-identification was more stable. That is why it was not surprising that the concept of Galician Rus' (Galician-Volhynian or Galician-Vladimir Rus') was significant at the time of the appearance in the 19th century of the local history works on the history of Galich and Galicia, historical intelligence and archaeological studies (Khrystan 2018, 160-174). A whole pleiad of the native-born authors of the historical Galician land considered it the integral part of the once seemingly single "world of Rus" that was formed during the times of princes. Thus, the idea of the indisputable and continuous historical community of the lands of Rus', which in the 19th and early 20th centuries were a part of the possessions, for example, of the Habsburg and the Romanov dynasties, is promoted in the life and works of Denys Zubrytskyy, Ivan Vahylevych, Markiyan Shashkevych, Yakiv Holovatskyy, Antin Petrushevych, Bogdan Didytskyy, Isydor Sharanevych (Khrystan 2018, 165-173), Ivan Franko ${ }^{19}$ and even Mykhailo Hrushevskyy ${ }^{20}$ and many other modern scholars. This was a result of the characteristic "Rus'ian" ("Ruthenian") pseudo- Galician researchers whose works, dedicated to Galicia, stimulated establishment of associations, societies and later also political parties.

So, to what extent were Galicia and Galich (part of) Rus' during the 11th-14th centuries? The question would be more than rhetorical even for the Rurik dynasty representatives on the thrones in Galich, Przemysl, Zvenygorod, Terebovlya and others like that.

As a component (albeit not permanent) of the possessions of the Rurikids, the bearers and "missionaries" of the concepts of Rus', Galicia and Galich from the 11th - 12th centuries were

19 Mykhailo Hrushevskyy, one of the most famous Ukrainian writers, was born in 1856 in the village of Naguevychi (now the village with the same title in Drohobych district of the Lviv region, Ukraine). He founded the Rus'ian-Ukrainian radical party (“Русько-Української Радикальної Партії”) (1890), and the Ukrainian-Rus'ian Publishing Union in Lviv (“Українсько-Руської Видавничої Спілки у Львові") (1899). He was one of the first initiators of the broader use of the Ukrainian identity, as opposed to the identity of the Rusyn. (Hrytsak 2006, 175-199).

20 It is worth paying attention to his work "Звичайна схема "русскої" історії й справа раціонального укладу історії східного слов'янства" ("The usual scheme of the "Rus'ian" history and the matter of the rational structure of the history of the Eastern Slavs") (1903), represented also in a multi-volume work "Iсторії України-Руси" ("The history of Ukraine-Rus") (1895 - 1933), where the stories of Galicia did not have an independent historical line, but they are described in context of the history of Rus' (Hrushevsyy 1991, 7-13). 
often associated abroad with the terms Ruthenia, Rutenia, Ruscia, Russia, Rossia etc. However, the prestige of the princes, the wealth of the elites, broad external contacts of the intellectual environment simultaneously strengthened in the history writings and official charters the term Galicia. A slow, but tireless "Rus'ification" ("Ruthenization") of the average citizen at the level of self-awareness began in the 12th century, especially after the coronation of Danylo as Rusciae Rex at the end of 1253, and the rise of Regnum Russiae. Hence both definitions (Galician and Ruscian) used in the sources and probably in the long oral tradition were doomed to coexistence and co-use. Galicia was more actively manifested in religious life of the 14th-18th centuries and in the management of Galician Land of Palatinatus Russiae. Ruthenian terminology was, however, more actively used by the scholars from Galicia in the 19th - 20th centuries in their research and political activities.

In modern historical studies and in the process of revision of the long-established historical narratives, often enshrined by the imperial ideology, which may operate using the terms that distort the perception of the historical past, there is a need to get rid of the previous load of illogical historiographical concepts. We hope this study contributes to that endeavour.

\section{REFERENCES}

Alfyorov, Oleksandr Anatoliyovych. 2012. Молівдовули київських князів другої половини XI кінця XII століття (за матеріалами сфрагістичної колекції О. Шереметьєва) [The bulls of the Kyivan Princes of the second half of the 11th - end of the 12th centuries (by the sphragistic collection of the O. Sheremetiev)]. In Сфрагістичний щорічник [Sphragistical yearbook] 2, 143-146.

Alfyorov, Oleksandr Anatoliyovych. 2016. Кириличні написи на княжій печатці (XI - XII ст.) [Cyrillic inscriptions on the princely seals (11th - 12th centuries)]. In Pokora, Piotr Hlebionek, Marcin - Kałuski, Tomasz (eds.). Inskrypcje na pieczęciach. Treści, formy, funkcje. Poznań, 9-16.

Alimov, Denis Yevgenievich. 2016. Этногенез хорватов: формирование хорватской этнополитической общности в VII - IX вв. [Ethnogenesis of the Croats: the formation of the Croatian ethno-political community in the 7th - 9th centuries]. Saint-Petersburg.

Avanesov Ruben Ivanovich (ed.). 1963. Смоленские грамоты XIII - XV вв. [The Smolensk acts of the 13th - 15th centuries]. Moscow.

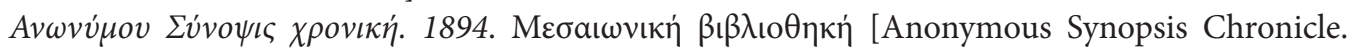
The Medieval Library]. In Kōnstantinos, Sathas N. (ed.). Bibliotheca Graeca medii aevi. VII. Paris.

Baran, Volodymyr Danylovych - Tomenchuk, Bogdan Petrovych - Figurnyy, Oleg Stepanovych. 2017. Давній Галич. Монографія [Ancient Galich. Monography]. Kyiv.

Bibikov, Mikhail Vadimovich. 2004. BYZANTINOROSSICA: Свод византийских свидетельств о Руси [ВYZANTINOROSSICA: The Summary of the Byzantine evidence about Rus']. Moscow.

Cross, Samuel Hazzard - Sherbowitz-Wetzor, P. Olgerd. 1953. The Russian Primary Chronicle. Laurentian Text. Cambridge.

Dąbrowski, Dariusz - Jusupović, Adrian (eds.). 2017. Chronica Galiciano-Voliniana (Chronica Romanoviciana). In Monumenta Poloniae historica. Kraków - Warszawa. nova series. XVI.

Ephraemii monachi imperatorum et patriarcharum recensus. 1840. In Corpus scriptorum historiae Byzantinae. XLIII. Bonnae.

Font, Márta. 2005. Árpád-házi királyok és Rurikida fejedelmek. Szeged. 
Font, Márta - Barabás, Gábor. 2017. Kálmán (1208 - 1241). Halics királya. Szlávonia hercege, Budapest - Pécs.

Forbes, Nevill, Michell, Robert (eds.). 1914. The Chronicle of Novgorod 1016 - 1471. London.

Franklin, Simon - Shepard, Jonathan. 1996. The Emergence of Rus, 750 - 1200. London.

Franklin, Simon - Shepard, Jonathan. 2009. Начало Руси [The Emergence of Rus'] 750 - 1200. Saint-Petersburg.

Gall, Franz. 1992. Österreichische Wappenkunde. Handbuch der Wappenwissenschaft. 2. Aufl. Wien.

Grechylo, Andriy Bogdanovych. 2008. Становлення символів Руського королівства (друга половина XIII - початок XIV ст.): версії, міфи й традиція [Formation of the symbols of the Kingdom of Rus' (the second half of the 13th - beginning of the 14th century): the versions, myths and tradition]. In Доба короля Данила в науці, мистецтві, літературі. Матеріали Міжнародної наукової конференції 29 - 30 листопада 2007 p. [The era of King Danylo in science, art, literature. The Materials of the International Scientific Conference, November 29 - 30, 2007]. L’viv, 260-276.

Gutsuliak, Oleg Borysovych - Drohomyretskyy, Petro Petrovych - Tomenchuk, Bogdan Petrovych. 2005. До проблеми Галичиної могили (Scando-Slavica у Верхньому Подністров'ї) [To the problem of Galician grave (Scando-Slavica in the Upper Transnistria)]. In Галичина : науковий і культурно-просвітній краєзнавчий часопис [Halychyna] 11, 14-26.

Hardi, Đura. 2002. Наследници Кијева измећу краљвске круне и татарског јарма: студила о державно-правном положају Галиче и Галичко-Волинске кнежевине до 1264. године [Heirs of Kyiv between the royal crown and the Tatar yoke: the study of the state and legal status of the Galician and Galician-Volhynian Principalities until 1264]. Novi Sad.

Hardi, Đura. 2018. Проблема першої згадки терміна “Галичина" в інтитуляції угорських королів [The issue of the first mention of Galicia in the intitulation of the Hungarian kings]. In. Nagirny, Vitaliy - Voloshchuk, Myroslav (eds.). Colloquia Russica. II. 4 : Medieval Rus': Problems of Terminology. Ivano-Frankivsk, 251-264.

Hrushevsyy, Mykhaylo Sergiyovych. 1991. Звичайна схема “русскої” історії й справа раціонального укладу історії східнього слов'янства [The usual scheme of the "Rus'ian" history and the matter of the rational structure of the history of the Eastern Slavs]. In Hrushevsyy, Mykhaylo Sergiyovych - Franko Ivan Yakovych - Kostomarov Mykola Ivanovych. Вивід прав України [Collection of the rights of Ukraine] L'viv, 7-13.

Hrytsak, Yaroslav Yosypovych. 2006. Пророк у своїй вітчизні. Франко та його спільнота (1856 - 1886). [A prophet in his homeland. Franko and his community (1856 - 1886)]. Kyiv.

Jakubovich, Emil - Pais, Dezső (eds.). 1998. P. magistri, qui Anonymus dicitur Gesta Hungarorum.

In Scriptores rerum Hungaricarum tempore ducum regumque stirpis Arpadianae gestarum. 1. Budapestini, 13-118.

Jusupović, Adrian. 2013. Elity ziemi halickiej i włodzimierskiej w czasach Romanowiczów (1205 1269). Studium prozopograficzne. Kraków.

Kashuba, Maria Vasylivna - Pikulyk, Nadiya (eds.). 2007. Києво-Печерський Патерик: видання друге, виправлене, пер. із церковносл [Kyiv-Pechersk Patericon]. L'viv.

Khrystan, Nazarii Mykhaylovych. 2018. "Нашъ Галичъ”: конструювання образу Данила Романовича у історичному наративі галицьких русофілів [“Нашъ Галичъ”. The constructing image of Danylo Romanovich in the historical narrative of Galician Russophiles]. In Voloshchuk, Myroslav Mykhaylovych (ed.). Галич: збірник наукових праць [Galich. Collection of scientific works]. Ivano-Frankivsk. 3. 160-174. 
Kloss, Boris Mikhaylovich (comp.) 2001a. Ипатьевская летопись [The Hypatian chronicle]. In Полное собрание русских летописей [The Complete Collection of Russian Chronicles]. 2. Moscow.

Kloss, Boris Mikhaylovich (comp.) 2001b. Лаврентьевская летопись [The Laurentian chronicle]. In Полное собрание русских летописей [The Complete Collection of Russian Chronicles]. 1. Moscow.

Kochkin, Igor Tarasovych - Nikitin, Alex. 2009. Mitochondrial DNA Sequence Variation in the Boyko, Hutsul, and Lemko Populations of the Carpathian Highlands. In Human Biology 81/1, 43-58.

Konovalova, Irina Gennadiyevna. 1999. Восточная Европа в сочинении ал-Адриси [Eastern Europe in the in the work of al-Adrisi]. Moscow.

Kotliar, Mykola Fedorovych. 2009. Київський літопис XII століття. Історичне дослідження [The Kyivan chronicle of the 12th century: historical research]. Kyiv.

Kozachok, Olga Bogdanivna. 2017. Відносини Галицького князівства з Візантією у контексті міжнародних зв’язків середини - другої половини XII століття : дисертація [The relations of the Galician Principality and Byzantium in the context of the international connections of the mid of the 12th - second half of the 13th centuries : the thesis]. L'viv.

Kuchkin, Vladimir Andreevich. 1995. “Русская земля” по летописным данным XI - первой трети XIII в. ["Rus'ian land" according the data of the chronicles of the 11th - the first half of the 12th centuries]. In Novoseltsev, Aleksandr Petrovich (ed.). Древнейшие государства Восточной Европы. Материалы и исследования 1992 - 1993 годы [The oldest states of the Eastern Europe. Materials and research of 1992 - 1993]. Moscow, 74-100.

Kupchynskyy, Oleg Antonovych. 2004. Акти та документи Галицько-Волинського князівства XIII - першої половини XIV століть. Дослідження. Тексти. [Acts and documents of the Galician-Volhynian Principality of the 13th - first half of the 14th century. Researches. Texts]. L'viv.

Liaska, Vitaliy Mykhaylovych. 2017. Голі Гори та Печера Домажирова: причинки до історичної географії галицько-волинського пограниччя у першій половині XIII століття [Holi Hory and Pechera Domazhyrova: comments to the historical geography of the Galician-Volhynian frontier in the first half of the 13th century]. In Nagirny, Vitaliy Mykolayovych - Voloshchuk, Myroslav Mykhaylovych (eds.). Colloquia Russica. II. 3 : Данило Романович і його часи [Daniel Romanovich and his times]. Ivano-Frankivsk - Kraków, 7-34.

Liwoch, Radosław. 2003. Stan badań nad grodziskami wczesnośreniowiecznymi i z początków późnego średniowiecza na zachodniej Ukrainie (obwody: iwano-frankiwski, lwowski i tarnopolski). In. Materiały i sprawozdania Rzeszowskiego Ośrodka Archeologicznego 24, 213-297.

Liwoch, Radosław. 2005. Militaria z dziewiętnastowiecznych badań w Podhorcach. In Acta Militaria Mediaevalia II. Kraków - Sanok, 37-59.

Liwoch, Radosław. 2006. Stan badań nad wczesnym średniowieczem ukraińskiego Przykarpacia. In Wczesne średniowiecze w Karpatach polskich. Krosno, 77-87.

Liwoch, Radosław. 2011. Uwagi o chronologii wczesnośredniowiecznych cmentarzysk na Zachodzie Ukrainy. In. "In silvis, campis... et urbe" : średniowieczny obrządek pogrzebowy na pograniczu polsko-ruskim. Sanok - Rzeszów, 89-100.

Liwoch, Radosław. 2018. Zabytki z wykopalisk Teodora Nieczuja-Ziemięckiego w latopisowym Pleśnisku (Podhorce na Ukrainie). Kraków.

Longinov, Arkadiy Vasilyevich. 1887. Грамоты малорусскаго князя Юрия II и вкладная запись князя Юрія Холмскаго XIV въка [The acts of the Lesser-Rus'ian Prince Yuriy II and the deposit record of Prince Yuriy Holmsky of the 14th century]. Moscow. 
Maineke, Augustus (ed.). 1836. Ioannis Cinnami Epitome rerum ab Ioanne et Alexio Comnenis gestarum. In Corpus Scriptorum Historiae Byzantinae. Bonnae.

Mayorov, Aleksandr Viacheslavovich. 2001. Галицко-Волынская Русь. Очерки социальнополитических отношений в домонгольский период. Князь, бояре и городская община [Galician-Volhynian Rus'. Essays of social-political relations in the Premongolian period. Prince, boyars and the city community]. Saint-Petersburg.

Mayorov, Aleksandr Viacheslavovich. 2006. Великая Хорватия: Этногенез и ранняя история славян Прикарпатского региона [Great Croatia: ethnogenesis and early history of the Slavs of the PreCarpathian region]. Saint-Petersburg.

Mykhailovskyy, Vitaliy Mykolayovych. 2013. Юрій II, Юрій-Болеслав Тройденович [Yuriy II, Yuriy-Boleslav Troydenovich]. In Енциклопедія історії України [The Encyclopedia of the history of Ukraine]. 10 : T - Я. Kyiv, 705-706.

Moravcsik, Gyula (ed.). 1967. Constantine Porphyrogenitus. 1967. De administrando imperio. Dumbarton Oaks.

Nagirny, Vitaliy Mykolayovych - Voloshchuk, Myroslav Mykhaylovych (eds.). 2018. Colloquia Russica. II. 4 : Medieval Rus': Problems of Terminology. Ivano-Frankivsk.

Nasonov, Arseniy Nikolayevich. 1951. “Русская земля" и образование территории Древнерусского государства: историко-географическое исследование [“Rusian land” and the formation of the Ancient Rus'ian state: historical-geographical research]. Moscow.

Nazarenko, Aleksandr Vasilyevich. 1999. Первые контакты Штауфенов с Русью (к истории русско-немецких отношений в 30-е годы XII века) [The first contacts of the Hohenstaufens with Rus' (to the history of the Rus'ian-German relations in the 30s of the 12th century)]. In Восточная Европа в исторической ретроспективе : к 80-летию В. Т. Пашуто [The Eastern Europe in the historical retrospective : to the 80th anniversary of Vladimir Pashuto]. Moscow, 166-179.

Obolensky, Dmitriy. 1971. The Byzantine Commonwealth. Eastern Europe, 500 - 1453. New York.

Odnorozhenko, Oleg Anatoliyovych. 2009. Родова геральдика Руського королівства та руських земель корони Польської XIV - XVI ст. [The generic heraldry of the Kingdom of Rus' and Rus'ian lands of the Polish crown of the 14th - 16th centuries]. Kharkiv.

Paszkiewicz, Henryk. 1996. Początki Rusi. Stopka, Kszysztof (ed.). Kraków.

Paszkiewicz, Henryk. 2020. Початки Галича [The Origins of Halych]. In Voloshchuk, Myroslav Mykhaylovych (ed.). Галич: збірник наукових праць [Galich. Collection of scientific works]. 6. Ivano-Frankivsk, 96-108.

Plokhy, Sergiy Mykolayovych. 2006. The Origins of the Slavic Nations Premodern Identities in Russia, Ukraine, and Belarus, Cambridge.

Procházková, Nataša. 2016. Титулатура короля Галичини Коломана (фрагмент дисертаційної роботи) [Titulature of the Galician King Koloman (the fragment of the dissertation)]. In Voloshchuk, Myroslav Mykhaylovych (ed.). Галич: збірник наукових праць [Galich. Collection of scientific works]. 1. Ivano-Frankivsk, 208-212.

Przyboś, Kazimierz (ed.). 1987. Urzędnicy województwa Ruskiego XVI - XVIII wieku (ziemie Halicka, Lwowska, Przemyska, Sanocka).Spisy. Wrocław-Warszawa-Kraków-Gdańsk-Łódź. Smičiklas, Tadij (ed.). 1904. Codex diplomaticus Regni Croatiae, Dalmatiae et Slavoniae. 2. Zagrabiae.

Skochylias, Igor Yaroslavovych. 2011. Галицька митрополія XIV - першої половини XV століть: особливості еклезіального правового та суспільного статусу [Galician metropolitanate of the 14th - the first half of the 15th century: the peculiarities of ecclesiastical, legal and social status]. In Княжа доба: історія і культура [Princely times: history and culture]. 4. 246-279. 
Tomenshuk, Bogdan Petrovych. 1999. Три періоди розвитку історичної топографії давнього Галича [Three periods in the development of the topography of Ancient Galich]. In Етнокультурні процеси в Південно-Східній Європі в I тис. н. е. [The ethno-cultural processes in South-Eastern Europe in the first millennium AD]. Kyiv - L'viv, 299-307.

Tomenshuk, Bogdan Petrovych. 2006. Археологія некрополів Галича і Галицької землі. Одержавлення. Християнізація [Archeology of the necropolises of Galich and Galician land. State formation. Christianization]. Ivano-Frankivsk.

Tomenshuk, Bogdan Petrovych. 2018. Археологія долітописного Галича, як культового і релігійного центру “Великої Білої нехрещеної Хорватії” (до питання про заснування Галича в другій половині Х ст.) [Archeology of the preannalistic Halych as a cultural and religious center of the "Great White unbaptized Croatia" (to the question of the founding of Halych in the second half of the 10th century)] In. Voloshchuk, Myroslav Mykhaylovych (ed.). Галич: збірник наукових праць [Galich. Collection of scientific works]. 3. Ivano-Frankivsk, $10-42$.

van Dieten, Ioannes Aloysius (ed.). 1975. Nicetae Choniatae Historia. In Corpus fontium historiae Byzantinae. 2. Berolini.

Vediushkina, Irina Vitaliyevna. 1995. “Русь” и “Русская земля” в Повести временных лет и летописных статьях второй половины XII - первой трети XIII в. [“Rus"” and "Rus'ian land” in the The Tale of Bygone Years and the articles of chronicles of the second half of the 12th the first third of the 13th centuries]. In Novoseltsev, Aleksandr Petrovich (ed.). Древнейшие государства Восточной Европы. Материалы и исследования 1992 - 1993 годы [The oldest states of Eastern Europe. Materials and research from 1992 to 1993]. Moscow, 101-116.

Voytovych, Leontiy Viktorovych. 2011. Галицько-Волинські етюди [The Galician-Volhynian etudes]. Bila Tserkva.

Voytovych, Leontiy Viktorovych. 2015. Галич у політичному житті Європи XI - XIV cт. [Galich in political life of Europe in the 11th-14th centuries]. L'viv.

Voloshchuk, Myroslav Mykhaylovych. 2010. Галицкая идентичность в XII - XIII вв.: земельный, династический и этнический аспекты [The Galician identity in the 12th - 13th centuries: the land, dynastic and ethnic aspects]. In Studia Slavica et Balcanica Petropolitana 1 (7), 165-178.

Voloshchuk, Myroslav Mykhaylovych. 2014. “Русь” в Угорському королівстві (XI - друга половина XIV ст.): суспільно-політична роль, майнові стосунки, міграції [Ruthenians (Rus') in the Kingdom of Hungary (11th - 14th Century): Their Social-Political Role, Property Relations, and Migrations]. Ivano-Frankivsk.

Voloshchuk, Myroslav Mykhaylovych (ed.). 2016-2020a. Галич: збірник наукових праць [Galich. Collection of scientific works]. 1-5. Ivano-Frankivsk.

Voloshchuk, Myroslav Mykhaylovych (ed.). 2016-2020b. Галич: збірник наукових праць [Galich. Collection of scientific works]. II. 1-5. Ivano-Frankivsk.

Voloshchuk, Myroslav Mykhaylovych. 2016. Переднє слово [The Foreword]. In Voloshchuk, Myroslav Mykhaylovych (ed.). Галич: збірник наукових праць [Galich. Collection of scientific works]. 1. Ivano-Frankivsk, 7-8.

Voloshchuk, Myroslav Mykhaylovych. 2017. Просопографічні студії битви під Ярославом 17 серпня 1245 року [Prosopographical Studios of the Battle near Yaroslav August 17, 1245]. In Nagirny, Vitaliy Mykolayovych - Voloshchuk, Myroslav Mykhaylovych (eds.). Colloquia Russica. II. 3 : Данило Романович і його часи [Daniel Romanovich and his times]. IvanoFrankivsk - Kraków, 103-122.

Voloshchuk, Myroslav Mykhaylovych. 2019. Проблеми інституалізації королівства Русі XIII $\mathrm{XV}$ століть: до постановки проблеми [The problems of the institutionalization of the 
Kingdom of Rus' of the 13th - 15th centuries: to the statement of the problem]. In Алманах Бъгарска украинистика [Almanac. Bulgarian Ukrainian Studies] 8, 84-95.

Welykyi, G. Athanasius, OSBM (ed.). 1953. Documenta Pontificum Romanorum Historiam Ucrainae Illustrantia (1075 - 1953). 1. Romae.

Wyrozumski, Georgius (ed.). 2005. Joannis Dlugossii. Annales seu cronicae incliti Regni Poloniae. Cracoviae.

Yurieva, Irina Sergeevna (comp.). 2017. Киевская летопись [The Kyivan chronicle]. Moscow. Zemek, Metoděj (ed.). 2003. Cronica domus Sarensis. Maior et minor. Brno.

Zholob, Anna Fedorivna - Koval, Igor Mykhaylovych - Stasiuk, Andriy Yevgenovych. 2018. Ярослав Пастернак - дослідник галицької Tрої [Yaroslav Pasternak - the researcher of "Galician Troy"]. In Voloshchuk, Myroslav Mykhaylovych (ed.). Галич: збірник наукових праць [Galich. Collection of scientific works]. II. 2. Ivano-Frankivsk.

prof. dr. hab. Myroslav Voloshchuk

Vasyl' Stefanyk Precarpathian National University

Faculty of History, Political Science and International Relations

Department of World History

Centrum Studiorum Mediaevalium

Shevchenko St., 57

76018 Ivano-Frankivsk

Ukraine

myrkomyrko79@gmail.com

ORCID: 0000-0002-1737-7205

Scopus Author ID: 57200183525

WoS Researcher ID: AAS-4803-2021 